\title{
Spinners and the Law: Regulating Yarn Standards in the English Worsted Industries, I 550-I 800
}

\author{
JoHN STYLES
}

The Worsted Acts, passed between I777 and I79I, established semi-official industrial police forces in nearly a third of the counties of England, charged with detecting and prosecuting fraudulent reeling of worsted yarn by hand spinners. The Acts have been interpreted as the response of late eighteenth-century employers to new and growing problems of labour discipline associated with the putting-out system. But frauds by spinners in reeling yarn were not new. They had characterised the worsted industry since its rapid expansion began at the end of the sixteenth century. Over the subsequent two centuries, employers addressed the problem repeatedly. How they tackled it depended crucially on the way the different regional worsted industries were organised and on dramatic changes in the willingness and capacity of the state to regulate manufacturing. The Worsted Acts emerge as the product of a distinctive eighteenth-century approach to industrial regulation, reactive and particularistic, but bureaucratically innovative.

\section{INTRODUCTION}

Textiles dominated English manufacturing during the eighteenth century. Most were made by hand under the putting-out system. Embezzlement of materials by workers has long been recognised as one of the key shortcomings of putting-out. 'In the eyes of the employer', declared Ephraim Lipson in his I92I history of the woollen and worsted industries, 'the most serious defect of the domestic [i.e. putting-out] system was the embezzlement of the raw material'. In the I970s Stephen Margolin went further, famously insisting that the chief incentive for employers to shift to centralised factory production during the Industrial Revolution was not the superiority of factory-based technologies, but the extent of embezzlement and associated problems of labour discipline under the putting-out system. ${ }^{2}$

Of course, efforts by employers to control embezzlement by outworkers pre-dated the arrival of the factory late in the eighteenth century. Indeed, many historians have argued that the eighteenth century as a whole witnessed a progressive intensification in the use of the criminal law to prevent embezzlement and similar frauds. They interpret new laws against embezzlement, enacted repeatedly by eighteenth-century Parliaments, as tools designed at the behest of employers to criminalise activities previously treated as breaches of trust, or to subject them to harsher penalties. The objective, it is argued, was either to confront problems of labour discipline that multiplied as the putting-out 


\section{Spinners and the Law}

system expanded, or to intensify the capitalist exploitation of labour by eliminating traditional and customary perquisites. ${ }^{3}$

Recent work casts doubt on these interpretations. The factory did not eliminate pilfering of materials by workers, nor did the new embezzlement acts engineer a onceand-for-all transformation of customary forms of appropriation of materials by workers into crimes. ${ }^{4}$ It is even questionable whether the new laws resulted in a general eighteenth-century intensification of prosecution for industrial embezzlement. ${ }^{5}$ There was, however, one type of employee fraud that did see an unprecedented surge in prosecutions - false and short reeling of yarn by hand spinners in the worsted industries of the north of England, the east Midlands and East Anglia. During the last quarter of the eighteenth century, prosecutions for this offence soared, with fifty to a hundred times more convictions per year than in the previous quarter century. ${ }^{6}$

This surge in prosecutions was principally the result of a series of acts of Parliament, subsequently known as the Worsted Acts, which by I79I applied to nearly a third of the counties in England 7 (Fig. I). They established committees of manufacturers elected by general meetings of worsted manufacturers in those counties. The committees nominated and directed the activities of inspectors, whose job was to detect and prosecute embezzlement offenders in general, but primarily spinners suspected of false and short reeling. The inspectors were licensed by the Justices of the Peace. Their salaries and the committees' expenses were met out of the drawback allowed manufacturers on the excise duty on soap used in the worsted industry. In effect, this was a semi-official industrial police force, established by statute, its manning regulated by Quarter Sessions, controlled in its day-to-day operations by the biggest employers in the industry and financed by what amounted to a compulsory levy on worsted manufacturers in general, imposed through the state's taxation machinery.

The Worsted Acts and their implementation have excited the interest of historians since the mid-nineteenth century. ${ }^{8}$ Yet analysis of their origins has been largely restricted to the local circumstances during the I760 and I770s which gave rise to the first of the Acts, passed in 1777 and applying only to Yorkshire, Lancashire and Cheshire. ${ }^{9}$ Explanations of the passing of the I777 Act are typically couched in terms of a narrowly focused problem-response model. Under conditions of hand production, it is argued, a successful, rapidly growing regional industry could secure sufficient yarn only by employing more and more spinners across an ever-expanding geographical area. Supervision became increasingly ineffective and frauds by spinners multiplied. Manufacturers responded by securing support from a sympathetic Parliament for a semi-official industrial police force to enforce the law rigorously. The Worsted Acts are interpreted, in other words, as the rational response of capitalist employers to intractable and growing problems of labour discipline inherent in the putting-out system, a response that was soon redundant, superseded by the spinning factory.

False and short reeling were not, however, new kinds of fraud which emerged only during the second half of the eighteenth century in the north of England. Attempts to control them stretched back across at least the previous two centuries, involving linen and cotton as well as worsted yarns. This long history prompts two questions which current explanations of the origins of the Worsted Acts, focused narrowly on the Yorkshire industry in the I760s and I770s, fail to address. First, why did the problem of controlling yarn standards in worsteds at the end of the eighteenth century come to be 
JOHN STYLES

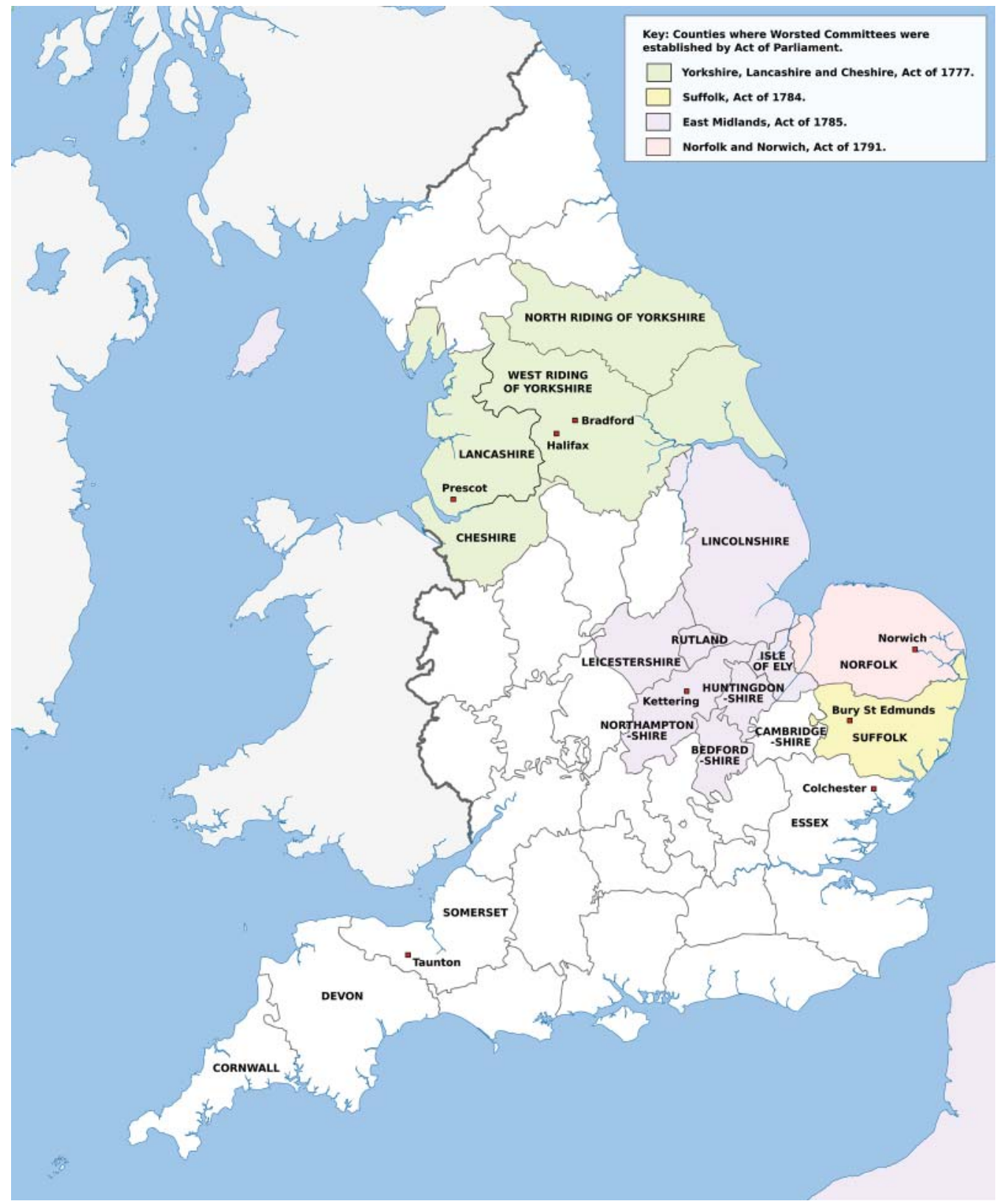

Fig. I. Principal English worsted spinning counties, c. I600 to c. I800. Adapted by the author from Wikipedia, File: English Counties I85I with Ridings (Online). Available from: en.wikipedia.org/wiki/File:English_counties_I85I_with_ridings.svg [Accessed I7 April 20I3]. 


\section{Spinners and the Law}

constructed primarily as an issue of enforcing penalties against employees? Second, how did industrial police forces established by several acts of the national Parliament, but restricted to one industry in certain counties, come to be accepted as a response to this problem that was not merely appropriate, but feasible? To answer the first of these questions, we need to consider the longer-term history of industrial organisation in the worsted industries and the nature of the firm. How were the different stages of production, of which spinning was only one, coordinated and standards (qualitative and quantitative) controlled as materials passed from stage to stage? To answer the second, we need to consider the longer-term history of economic regulation and law making. What were the options for creating and enforcing officially endorsed rules for the worsted and other industries?

As we have seen, existing studies of the Worsted Acts have engaged principally with historical debates focused on the eighteenth century: debates about the role of labour discipline under the putting-out system in stimulating the transition to factory production and debates about the use of the eighteenth-century criminal law as a tool to transform popular customs into crimes. Examining false and short reeling across a longer period, from the sixteenth to the eighteenth centuries, obliges us to engage with a different set of debates, concerned with the impact of official institutions - corporate, municipal and national - on early modern manufacturing. ${ }^{10}$

The recent flowering of this second set of debates reflects, in part, the impact of the new institutional economics on early modern European economic history. Especially relevant for understanding false and short reeling is the transaction cost approach that has informed reassessments of the contribution made by guilds to economic progress and industrial innovation in medieval and early modern Europe. ${ }^{\text {II }}$ In textiles, as in other industries, transaction costs were incurred as materials moved between different stages of production, whether those transfers took place within a firm or between different firms. Such transfers required checks on the standard to which the material had been worked at the previous stage. In an early modern world where materials were physically inconsistent, tools imprecise and workers variable in skill and dexterity, establishing those standards and ensuring they were upheld was costly. ${ }^{\mathrm{I} 2}$

However, recent debates about the impact of institutions on early modern manufacturing also expose dissatisfaction with the new institutionalists' narrow focus on economic efficiency. An alternative approach, drawing on the economics of conventions, emphasises the importance of the tacit norms and rules - the shared conventions that constitute and legitimate markets. The focus here is cultural, social and political. How were shared notions of quality constituted by participants in different kinds of product market? How was trust in quality generated along supply chains? When and how did these shared 'quality covenants' secure official endorsement? ${ }^{13}$ The productcentred character of this approach is particularly valuable for the study of false and short reeling, alerting us to the way a product's material characteristics can shape the organisation and co-ordination of its manufacture. ${ }^{\text {I4 }}$

\section{FALSE AND SHORT ReELing}

False and short reeling were frauds committed by hand spinners. The worsted industries were distinguished by their use of long-staple, combed wool. Spinning was one of a 
number of production processes to which the raw wool was subjected on its way to becoming worsted cloth. It differed from the other stages of production in a number of respects. Worsted spinning was mainly undertaken on an outwork basis by employees on piece rates, predominantly women (although in some of the poorer upland agricultural areas of north-west Yorkshire the proportion of men in the spinning labour force could be as high as a quarter $\left.{ }^{15}\right)$. The numbers employed in spinning far outnumbered those employed in the other processes in the industry. It was estimated in 1774 that in the Yorkshire industry spinners outnumbered woolcombers and weavers (the principal male occupations in the worsted industry) by more than three to one. ${ }^{16}$ As a consequence of this numerical imbalance, spinning work extended geographically far beyond the confines of those areas of male employment which historians have conventionally defined as the worsted manufacturing regions. By I790 worsted manufacturers in the BradfordHalifax area of the West Riding of Yorkshire were putting out spinning forty to fifty miles away, both in mid-Cheshire to the south-west and in Swaledale to the north, and almost as far afield in other parts of Yorkshire and Lancashire. A century earlier, it was claimed that the Norwich worsted industry drew its yarn supplies from similar distances across the counties of Norfolk, Suffolk, Essex, Cambridgeshire and the Isle of Ely. ${ }^{17}$ Putting wool out to be spun at any distance from the manufacturer's base involved the employment of agents, often shopkeepers, to distribute the wool in the spinning localities.

The many different varieties of worsted cloth required yarns of a wide range of fineness. The coarser the yarn, the easier it was to spin. Hence coarser spinning commanded lower piece rates. The combed wool used in making worsteds was sorted according to the fineness of spinning required and was then delivered out by weight. The particular standard of fineness to which the yarn was to be spun was specified in terms of the length of yarn to be produced from each pound weight of wool. It had been usual from at least the sixteenth century for worsted spinners to return the yarn reeled into set lengths, known as hanks or skeins. ${ }^{18}$ The length of a hank was expressed as a fixed number of coils or revolutions (known as threads) on a reel of a particular size.

Reeling could be performed in a number of ways. The simplest and cheapest form of reel commonly used by spinners was the reel staff. ${ }^{19}$ It consisted of a wooden rod half the length of the standard thread, equipped with cross bars at each end to hold the yarn (Fig. 2). These were already familiar implements during the later Middle Ages. ${ }^{2 \circ}$

Circular, revolving reels mounted on an axle were faster, but more expensive. The functionality of revolving reels could be further enhanced by devices to signal or count the number of revolutions, driven by gears from the axle. Snap or jersey reels made a sound after a certain number of revolutions, while clock reels had a clock-like face with a pointer indicating the number of threads reeled (Fig. 3). In addition, markets where yarn was sold might be equipped with fixed reeling devices. It was claimed in I6I6 that in every market town in Norfolk 'a paire of iron pinnes were driven into a post at half a yearde distance, for measuringe the said yearne'. ${ }^{21}$

The different worsted industries and districts used reels of different sizes and hanks of different numbers of threads. ${ }^{22}$ These local standards were said to be customary and appear to have pre-dated formal codification. In the eighteenth-century Yorkshire worsted industry, for example, the reel was usually one yard in circumference and 560 


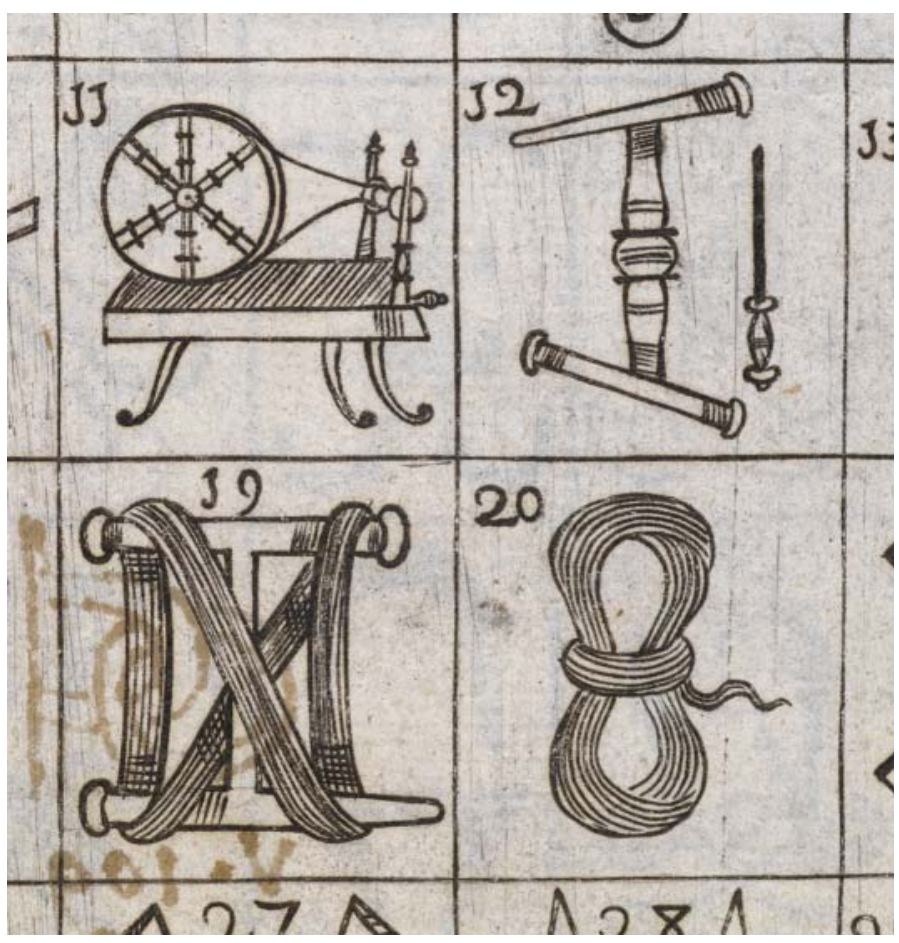

FIG. 2. Reel staffs and reeled yarn, late seventeenth century, printed engraving. II: a spinning wheel. I2: an empty reel staff (left). I9: a reel staff loaded with a hank or skein of yarn. 20: a hank or skein of yarn removed from the reel. Proof plate (detail) for Randle Holme, The Academy of Armory (Chester: I688), Book 3, ch. 6 . (C) The British Library Board, Harleian MS 5955 , f. 38 .

threads (or 560 yards) constituted a hank. The number of such hanks in a pound of yarn provided a measure or 'count' of the fineness of the yarn. The types of yarn required by a Yorkshire manufacturer of shalloons in the late eighteenth century ranged from counts as low as eighteen hanks to the pound to as high as thirty-six hanks to the pound. The rate paid in Yorkshire in the early I770s for spinning yarn at twenty-four hanks to the pound was approximately 25 per cent higher than that for eighteen hanks to the pound. ${ }^{23}$

False and short reeling were technically separate frauds, although most offenders were convicted for the two jointly. False reeling involved the yarn being deficient in the number of threads, although reeled on a reel of the standard size. Short reeling involved the yarn being reeled on a reel of less than the standard circumference. ${ }^{24}$ Thus in southwest Lancashire in 1785 , Betty Dagnell, wife of a Prescot labourer, was convicted for reeling a hank of worsted yarn short by 35 yards ( 6 per cent), although reeled 'on a reel of a proper gauge', while Ellen Atherton, a widow from nearby Huyton, was convicted on the same day for reeling a hank short by 15 yards ( 3 per cent) 'on a reel of an under gauge'. ${ }^{25}$ In practice, both offences involved the spinner producing yarn shorter than that specified by the manufacturer. By these methods, the spinner could take advantage of her employer in at least two ways. She could appropriate some of the wool delivered to her to spin, or reduce her workload by producing yarn of a coarser and therefore less demanding count than that paid for, or she could benefit by some combination of the two. 


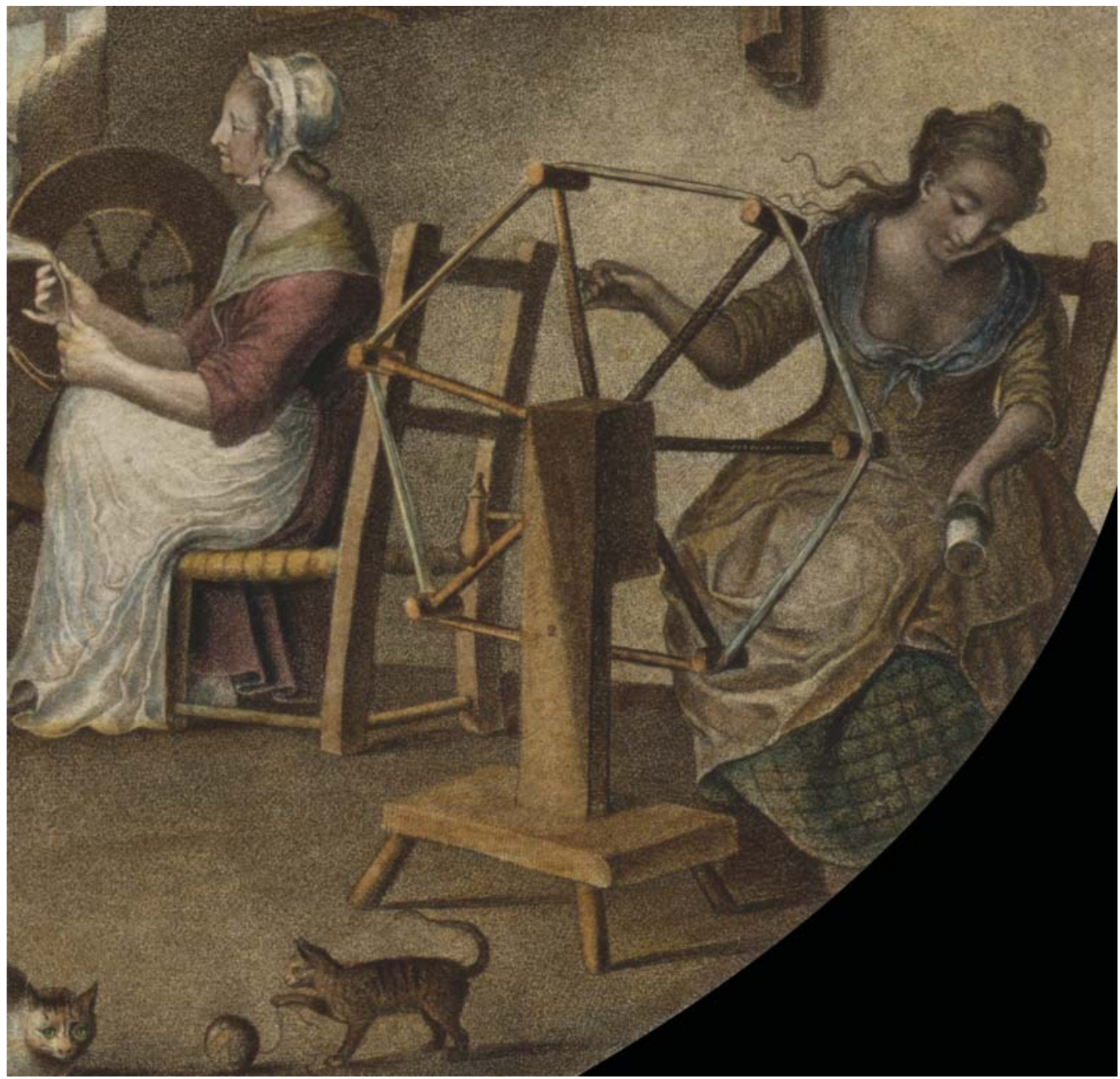

FIG. 3. Reeling linen yarn on a revolving clock reel, Ireland, I782. Gears inside the box at the top of the pillar connected the reel's axle to a pointer on a clock-like face, visible to the reeler, indicating the number of revolutions. This was the most sophisticated and probably the most expensive form of reel. Detail from William Hincks, 'To the right hon'ble the Earl of Moira, this plate, taken on the spot in the County of Downe, representing spinning, reeling with the clock reel, and boiling the yarn', hand-coloured engraving, 1782 .

Library of Congress, Washington, DC, Prints and Photographs Division, Reproduction Number LC-USZC4-II2I9.

False and short reeling were activities confined neither to the worsted industry nor to the eighteenth century. Given that the value of yarn varied in all the textile industries according (at least in part) to the fineness to which it was spun, the potential for this kind of deceit existed wherever yarn was the object of a commercial transaction. This was true irrespective of whether that transaction was between the spinner and an 


\section{Spinners and the Law}

employer who paid her a wage to work up raw material that remained his property, between an independent spinner who owned the raw material she worked up and a customer to whom she sold the finished yarn, or between a yarn dealer who carried a stock of yarn supplied by others and a manufacturer who bought that yarn to make up into cloth.

In none of these transactions was the deceitful supply of false and short reeled yarn treated as simple theft under English law. Even where the spinner deceitfully worked up materials that remained the property of her employer with the aim of keeping part for herself, the fraud could not be tried on indictment as larceny at Quarter Sessions or the Crown Side of Assizes, in contrast to most thefts. This was because it was a general rule of English common law that larceny could not be committed by those to whom possession of the goods in question had been legally transferred by their owner, as was the case under the putting-out system. The primary legal remedy in such a case was an action for damages in the civil courts, just as it was when fraudulent yarn was sold deceitfully. However, a civil action was not always practical. It was one thing for a large manufacturer to use cumbersome and costly civil court procedures to remedy a bulk purchase of defective yarn from a yarn merchant, but it was a different matter altogether for a small weaving master to go to court to secure damages against a poor spinner who kept back a few ounces of wool worth only pence. Between the later Middle Ages and the end of the eighteenth century, Parliament provided, therefore, a succession of statutes, including the Worsted Acts, to enable cases between employers and outworkers accused of embezzling materials to be submitted to cheap and accessible summary adjudication by Justices of the Peace. ${ }^{26}$

Insofar as false and short reeling was an issue in the relationship between employer and employee during the seventeenth and eighteenth centuries, it was, to a peculiar extent, associated with the worsted industry. The problem of false and short reeled yarn was also widespread in the linen industry. However, most of the yarn used in commercial linen manufacturing was imported, especially from the eastern Baltic and later from Ireland. Moreover, much English-spun linen yarn was produced not by waged workers, but by independent spinners working flax they had grown or purchased themselves into yarn to sell. In these circumstances, illegality arose from the spinner putting fraudulent yarn on sale, not from any breach of her employment contract under the putting-out system. ${ }^{27}$ False and short reeling of cotton yarn became an important issue in Lancashire in the middle years of the eighteenth century, when pressure on yarn supplies became acute and the range of cotton and semi-cotton fabrics was fast expanding. In the cotton industry, however, the false and short reeling issue was quickly resolved after the I760s by the rapid shift from hand-spun to jenny- and frame-spun yarn. ${ }^{28}$

The absence of expressions of concern about false and short reeling is more perplexing in the case of the woollen industry, which employed short-staple, carded wool. In many of its branches, spinning had been organised along putting-out lines since the Middle Ages. Woollen cloth manufacturers were much exercised about frauds by outwork spinners from the early sixteenth right through to the later eighteenth centuries, but their main concern was embezzlement of the raw wool rather than defects in the quality of the yarn. ${ }^{29}$ Piece rates for spinning short-staple wool were often paid according to the weight of yarn spun rather than its precise count (although some account was 
usually taken of the fineness of the spinning), in contrast to worsteds where piece rates were almost always paid according to the count of the yarn. ${ }^{30}$

The main reason for the difference was probably the nature of the product. Woollen cloth, unlike many worsteds, was fulled to provide a raised nap. The individual threads were not visible in the finished cloth. Consequently, the yarn's twist and softness could be more important for the final appearance of a woollen cloth than the exact fineness and consistency of the spinning (Fig. 4). Moreover, the short staple wool used in the production of woollens was often put-out to be both spun and carded by the same person or family. Together these processes involved wastage and oiling, both of which could be manipulated to conceal embezzlement. The long-staple, combed wool used in worsteds was delivered to the spinners already combed and oiled, and could not be manipulated in the same way (or at least to the same extent). In addition, pure worsteds were not fulled, so the individual yarns remained visible in the surface of the woven fabric, rendering the look of the finished product highly dependent on the precise fineness and consistency of the spinning (Fig. 5). Even in lightly fulled semi-worsteds like bays and serges, with a worsted warp and a woollen weft, the individual yarns were often visible.

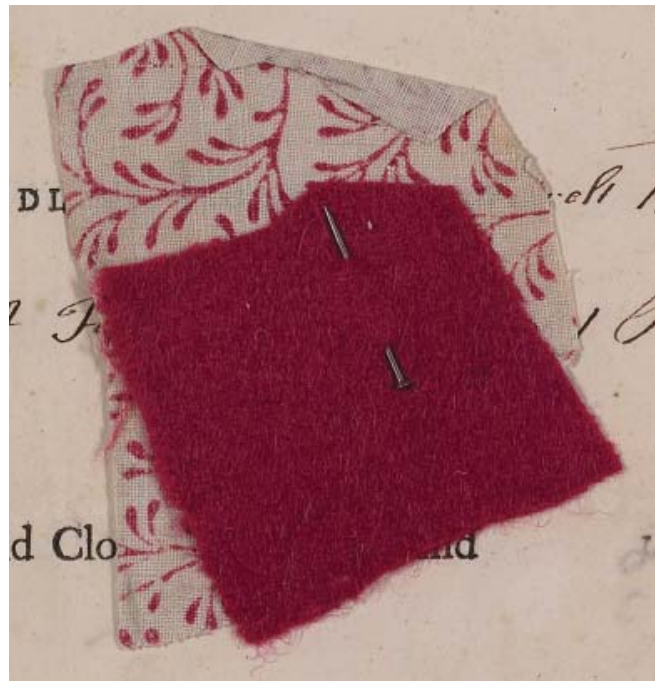

FIG. 4. 'Red Cloth' and 'Spriged Linen', I759. On top, a woollen cloth, dyed red; underneath, a white linen printed with red sprigs. The individual yarns are not visible in the fulled and napped woollen cloth, in marked contrast to the printed linen.

(C) Coram. Image copyright London Metropolitan Archives, City of London, Foundling Hospital Billet Books, Foundling no. I2058 (ref. A/FH/A/9/I/I35).

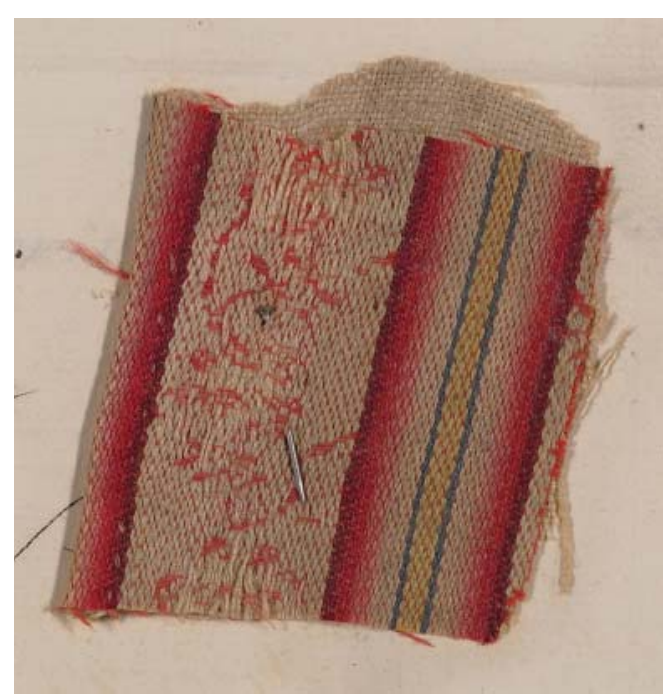

FIG. 5. 'Striped Calimanker', I759. On top, a calamanco, an all-worsted fabric woven in red, yellow, and brown stripes with a flowered pattern; underneath, a brown linen. The individual coloured yarns from which the calamanco is woven are clearly visible.

(C) Coram. Image copyright London Metropolitan Archives, City of London, Foundling Hospital Billet Books, Foundling no. I2056 (ref. A/FH/A/9/I/I44). 
It was in the worsted manufacture, therefore, that false and short reeling by outworkers occasioned the longest-standing and most vocal anxiety among employers and users of yarn. This was true from soon after the establishment of the 'new draperies' employing combed wool during the later sixteenth century, until the very rapid demise of handworsted spinning in the years after the introduction of power spinning at the end of the eighteenth century. ${ }^{3 \mathrm{I}}$ Far from conforming to a conventional image of pre-industrial stasis and immobility, the hand worsted industries that flourished from the sixteenth to the eighteenth centuries comprised one of the country's most dynamic industrial sectors, especially in terms of exports. ${ }^{32}$ They were geographically mobile and regionally diverse. Neither their organisation nor their location remained constant during this long period. Both influenced the character and control of false and short reeling.

Although the production of various kinds of worsted and semi-worsted fabric became widespread in England during the seventeenth and eighteenth centuries, there were four principal core weaving areas — Norwich (with north-east Norfolk), Essex (with parts of south Suffolk), Devon (with parts of west Somerset) and the West Riding of Yorkshire (with parts of east Lancashire). ${ }^{33}$ These areas served distinct markets, produced particular types of cloth, and prospered at different times. The Norwich industry grew very rapidly from the late sixteenth century and continued growing, with some setbacks, until the mid-eighteenth century. It concentrated on high quality all-worsteds and worsted-silk mixes, and was largely unchallenged in this specialism by any other branch of the domestic worsted industry (with the exception of manufacturers in the Spitalfields district of London) until the later eighteenth century. ${ }^{34}$ The Essex industry also grew rapidly from the late sixteenth century, flourished until the early eighteenth century, and then went into an uneven and protracted decline that lasted until the end of the eighteenth century. It specialised in middle and low quality all-worsteds and wool-worsted mixes, particularly bays and says. ${ }^{35}$ The Devon-Somerset industry also concentrated on middle quality wool-worsted mixes, especially serges. It underwent a very rapid expansion in the second half of the seventeenth century, and an equally rapid decline in the first half of the eighteenth century. By the end of the eighteenth century it had virtually disappeared. ${ }^{36}$ In the West Riding, the industry developed only from the start of the eighteenth century, initially producing middle and low quality cloths like bays and shalloons, in competition with Essex and other smaller centres in the South and the Midlands (especially Kettering in Northamptonshire). It grew rapidly through the century, moving into higher quality all-worsted fabrics after 1750 and eventually leading the transition to factory spinning. ${ }^{37}$

These areas differed in the way spinning was organised and integrated with the other production processes. Of the worsted districts that flourished in the seventeenth century, it was in Norwich and in Essex that false and short reeling emerged as a major issue. Frauds by spinners in the zone supplying yarn to the booming Devon and West Somerset serge industry in the late seventeenth and early eighteenth centuries did not excite much comment. A petition to Parliament from Taunton in Somerset initiated the process leading to the first embezzlement Act to include general provisions against false and short reeling in $1703 .{ }^{38}$ However, the Taunton petition was concerned with apprenticeship. It is likely that the initiative to include false and short reeling in the Act came 
not from the West Country, but from Norwich. Embezzlement provisions, including those for false and short reeling, were added only once the Taunton petition was under consideration by a parliamentary committee comprised mainly of MPs from other areas, including Norwich. False and short reeling of yarn destined for the Norwich worsted industry had in the I690s been the subject of a failed parliamentary bill and an accompanying pamphlet war, in which corporal and other punishments were demanded for offending spinners. ${ }^{39}$ The lack of engagement with false and short reeling in the West Country probably reflected the area's focus on serges, semi-worsteds often with a napped surface that hid the yarn, and its reliance on large quantities of worsted yarn from Ireland, where there was legislation in $\mathrm{I} 733$ to prevent false and short reeling of worsted yarn intended for export to Great Britain. ${ }^{4}$

Spinning for the Norwich and Essex industries was organised in contrasting ways from the late sixteenth century. Both were characterised by firms run by master manufacturers employing workers, often on a putting-out basis, but the Norwich industry was vertically disintegrated, with a division between the enterprises that undertook weaving and the enterprises that undertook woolcombing and spinning. The Norwich manufacturers drew yarn from large areas of East Anglia and the Fens. Woolcombing was undertaken in Norwich itself and in various centres within the spinning areas (such as Bury St Edmunds in Suffolk). The combed wool was put out to spin by a multiplicity of master woolcombers and yarnmasters. The finished yarn was then transported to Norwich and sold to the master weavers there. Until the middle years of the eighteenth century, Norwich weaving was dominated by men with fairly small capital, employing perhaps half a dozen journeymen. In I7I9 there were said to be about five hundred master weavers in Norwich..$^{4}$

The advantage of vertical disintegration for the Norwich industry probably lay in the immense and fast-changing range of high-quality fabrics the city produced, requiring a corresponding diversity of yarns. In I6II, Norwich stuffs were already being described as being 'of infinite varietie of sortes, figures, coullors and prices'. The need for constant innovation was stressed: 'our trade is most benefitted by o[u]r new inventions and the varyinge of $\mathrm{o}[\mathrm{u}] \mathrm{r}$ stuffes which is contyn[ually] profitable'. ${ }^{2}$ Specialist yarn suppliers were better placed to meet fluctuating demand for a multiplicity of yarn specifications than vertically integrated manufacturing firms employing their own spinners. ${ }^{43}$ However, vertical disintegration risked raising transaction costs by relying on the market rather than direct supervision to coordinate the supply of yarn - a key intermediate good - and by dividing the supervision of standards between separate businesses with potentially conflicting interests.

In Essex, by contrast, where the range of worsteds produced was narrower and more consistent, there was a much stronger tendency for firms to be vertically integrated, to be more heavily capitalised and to employ larger numbers of workers. The worsted industry in the various weaving towns - Colchester, Bocking, Braintree, Sudbury, Coggeshall and Halstead - was dominated by a relatively small number of large manufacturers who employed the combers and weavers, and put wool out to be spun in the Essex countryside. K. H. Burley estimates that by the early eighteenth century at Colchester, the principal centre of the Essex industry, there were between fifty and a hundred manufacturers employing on average between sixteen and twenty-six weavers each, as well as many more combers, spinners and finishers. ${ }^{44}$ 


\section{Spinners and the Law}

False and short reeling became an object of complaint by employers in the Essex and the Norwich industries early in their development, as pressure on the supply of spinning labour rapidly increased. By the early seventeenth century both were seeking officially sanctioned regulation. To what extent this involved new forms of control is difficult to assess, as it is far from clear precisely what remedies putting-out employers in general already had against frauds by their employees. Given the looseness with which statutes providing summary penalties against idle and disorderly behaviour among the labouring poor appear to have been applied by the Justices of the Peace, in practice employers may sometimes already have had punitive sanctions readily available to them..${ }^{45}$ Even if this were true, however, worsteds in both Norwich and Essex at this period were emerging industries in which manufacturers evidently felt a need for new, less ambiguous means of control.

What is most striking about the forms of official regulation sought by employers in the two industries at this early period is the extent to which they differed. The response of the Essex manufacturers to false and short reeling was through parliamentary legislation. They inserted into an Act of I609 against embezzlement by workers in the woollen industries a clause specifying dimensions for reeling and making false and short reelers liable to the same penalties as workpeople who embezzled materials. ${ }^{46}$ Unlike the rest of the Act, this clause applied only to yarn supplied to worsted manufacturers in six named towns in Essex. The Act provided for summary adjudication of such cases by magistrates, for recompense to be paid to the employer and for corporal punishment of offenders who were unable to make recompense. The latter appears to have been the key provision, as the Act claimed that offenders were 'poor and altogether unable to make recompence or satisfaction'. ${ }^{47}$

Because the Essex manufacturers ran vertically integrated firms, employing the women who spun their wool, it was necessary that any new controls should bear directly on the spinners. Moreover, if those controls were to involve corporal punishments, it was important they should be established by statute, because by the early seventeenth century it was increasingly held to be unacceptable to impose such punishments through other forms of quasi-legislative enactment, such as royal proclamations, charters or guild ordinances. At Colchester, the industry was organised into companies or guilds dominated by the master manufacturers - the Dutch and English companies - chartered by the borough authorities and subsequently, in the case of the Dutch corporation, by an Act of Parliament in $1660.4^{4}$ Similar guilds appear to have existed in other Essex weaving towns. ${ }^{49}$ The Colchester companies had powers to make by-laws and search for faulty work within the borough and liberty of Colchester, but spinning extended out into the Essex countryside, far beyond Colchester's boundaries. The I609 Act of Parliament provided worsted manufacturers in Colchester and the other Essex weaving towns unambiguous powers to prosecute and punish false and short reeling by spinners who worked for them anywhere in the county.

The options available to the Norwich master weavers were different. Two characteristics of the economic and institutional environment in which they operated enabled them to concentrate their efforts on the sellers of defective yarn rather than on the spinners themselves. The first was the vertically disintegrated organisation of the Norwich industry, the second the wide range of options available in seventeenth-century England for making, enforcing and securing the state's endorsement of industrial regulation. The 
price the industry paid as the master weavers exploited these options was chronic tension between its two principal stakeholders - the weavers and the yarn suppliers.

The Norwich weavers bought yarn from the master woolcombers and yarnmakers who employed spinners in the countryside in Norfolk, Suffolk and beyond. So insofar as the quality of yarn was a problem that required remedy, they had the option of dealing with it by policing the sale of yarn by the master woolcombers and yarnmakers, unloading the responsibility for control of the spinning workforce on to them. Throughout the period of rapid growth of the Norwich worsted industry during the late sixteenth and seventeenth centuries, the city's master weavers were organised in a succession of companies, some authorised by statute and others by municipal authority, culminating in an Act of the Interregnum Parliament giving extensive powers to a reconstituted worsted weavers' company in 1650 , renewed after the Restoration by an Act of I662.5० These successive weavers' companies enjoyed powers to regulate standards in the industry, including powers to search for faulty work and secure forfeitures and fines. Prior to I700, searches, forfeitures and fines of this sort did not have to be authorised by parliamentary legislation. ${ }^{\text {I }}$ To ensure the quality of yarn put up for sale, the city's weavers drew on several different kinds of official rule-making. In I6I7, for example, the worsted weavers' company secured a Privy Council order to confirm the authority it already enjoyed under a city ordinance to regulate sales of defective yarn. Subsequently, the same powers were incorporated into the Acts of Parliament of 1650 and $1662 . .^{52}$

In the course of the seventeenth century, the weavers repeatedly used their powers of search and forfeiture against woolcombers and yarnmasters from Norfolk, Suffolk, Essex and Cambridgeshire who supplied defective yarn to Norwich. Searches were undertaken mainly as yarn was brought into the city or put on public sale there. The woolcombers and yarnmakers responded by challenging the weavers in the higher courts, petitioning the Privy Council and Parliament, opposing the weavers' company legislation of I650 and I662. In I693, they even tried to persuade Parliament to incorporate them by statute into a woolcombing and worsted yarn company. They argued that the number of spinners was huge and that it was physically impossible to check all the yarn received from spinners before it was sold. They claimed that disciplining the spinners by dismissing them was not effective because they could always find work with another master. The Norwich weavers replied that the master woolcombers and yarnmakers in fact connived at the spinners' frauds, that false and short reeling was easily prevented by checking the yarn, and that the woolcombers and yarnmakers should secure legislation to punish offending spinners similar to the Act obtained in I609 by the Essex manufacturers. ${ }^{53}$

The terms of this dispute are revealing of the ambiguity of employers' attitudes to false and short reeling. Attitudes to this and other kinds of fraud by workers were not uniformly or consistently hostile. ${ }^{54}$ Nor was the use of the law the obvious control technique of first resort. Employers' attitudes to these offences and their responses to them varied according to the structure of the industry and the state of the product and labour markets. The Norwich weavers may have been correct to argue that the master woolcombers and yarnmakers could have checked at least some of the yarn, but the latter were also right to emphasise that, in an industry where numerous spinning masters were involved in intense competition for labour, the threat of dismissal or even prosecution 


\section{Spinners and the Law}

would harm not the deceitful spinner but the master. The tightness of the spinning labour market in East Anglia is illustrated by the long-term expansion of spinning for the Norwich industry into the north of England in the course of the seventeenth and early eighteenth centuries. ${ }^{55}$

The pressures on the master woolcombers and yarnmakers to tolerate false and short reeling were reinforced by the organisational divide between the weaving and the spinning branches of the industry. The master woolcombers and yarnmakers did not have to confront the problems poor quality yarn could create for weaving, and there is little doubt that checking all the yarn would have been cumbersome. As long as demand was such that false and short reeled yarn found a ready sale, there was little incentive for them to control the fraud. Indeed, the ubiquity of false and short reeling suggests that it was often tolerated.

\section{Industrial Organisation and Regulatory Repertoire: The Eighteenth Century}

The seventeenth-century experience is important because it illustrates how the choice of different strategies to control a particular type of fraud by industrial workers could be influenced by differences in the structures of the industries concerned. Not that these were the only influences at work shaping the choice of strategy. The character of the machinery for securing the state's authority for regulation was also crucial. In the seventeenth century, parliamentary legislation enjoyed some advantages over other forms of official rule making, especially with regard to punishments, but before the Glorious Revolution of I688 Parliaments did not necessarily meet every year. When they met, it was often only for a few months at a time, and sessions were liable to be suddenly and unpredictably cut short by prorogations or dissolutions. These were real obstacles to using Parliament to enact industrial regulation. In I62I, the Privy Council redirected a petition from weavers of worsted, baize, says, stuffs and fustians in Norfolk, Suffolk and Essex to Parliament. The purpose was to secure an Act that would (among other things) have imposed punishments on spinners convicted of false and short reeling before a Justice of the Peace. It was 'well approved of by the whole house of Parliament, yet by reason of the suddaine dessolucon of the said Session, nothing was done therein'. ${ }^{6}$ Parliament met during only four of the next eighteen years and provisions of the kind the weavers sought were not enacted until 1703 .

Before I640 these obstacles to parliamentary legislation did not represent a fundamental weakness in government because the Privy Council was the leading executive and administrative body of the kingdom and could in effect legislate by means of royal proclamations, patents and charters. Although in theory parliamentary statute was superior, in practice Parliament often operated as an auxiliary to the Privy Council. After I660, the powers of Privy Council were dramatically curtailed and Parliament, to some extent, filled the vacuum. But it was only after the Glorious Revolution of I688 that Parliaments invariably met annually and on a regular pattern, almost never for less than four months and sometimes for as many as six. One effect of this change was to create a vast new capacity for parliamentary legislation, including economic legislation, but a capacity that could only be used for those modes of regulation that Parliament and the courts found palatable. ${ }^{57}$ 
While Parliament's capacity to make law was expanding at the expense of other modes of legislating, the range of alternative institutions available to regulate manufacturing was rapidly narrowing. Numerous attempts were made during the seventeenth century to enforce standards and regulate quality in the different branches of textile manufacturing, mainly by establishing guilds of clothiers and master manufacturers for particular types of cloth in particular areas, either by royal charter or by Act of Parliament. ${ }^{58}$ These attempts were only intermittently successful, but they came to an end after the Glorious Revolution, with the curtailment of the royal prerogative and the ascendancy of political and legal attitudes hostile to corporate privilege. The Witney blanket weavers' company of I7II was the last new guild chartered to regulate all aspects of production in a local textile industry. At the same time, and probably not coincidentally, pre-existing manufacturing guilds went into decline. ${ }^{59}$ In worsteds, the Colchester Bay Hall corporation ceased functioning in the $17205 .{ }^{60}$ The Norwich weavers' company appears to have ended its activities in the same decade. A new body, the Committee of Trade, which had emerged at Norwich by 1736, had no official status. A private association of manufacturers dedicated to lobbying in defence of the city's worsted industry, it exercised none of its predecessor's supervisory functions. ${ }^{6 \mathrm{r}}$

In Yorkshire, of course, worsted manufacture became well established only in the early eighteenth century, so a chartered corporation to regulate the industry on seventeenth-century lines was not an option. The Yorkshire industry, like the Essex industry, was dominated by vertically integrated firms, but, by the second half of the century, was noted for its very large number of master manufacturers. False and short reeling first became a matter of public complaint in the industry in I764, at the end of a period of rapid growth in the later years of the Seven Years War. ${ }^{62}$ The chronology appears to be broadly similar to that in East Anglia one hundred and fifty years earlier. Concern with false and short reeling arose once the industry had grown large enough for there to be acute spinning labour shortages during phases of industrial prosperity. However, it also reflected a shift after I750 away from the coarser, simpler fabrics, especially shalloons, characteristic of Yorkshire worsteds earlier in the century, towards higher-quality fabrics, such as calamancoes, russels, everlastings, tammies and figured stuffs, requiring better quality yarns. ${ }^{63}$ In a vertically integrated industry, manufacturers experienced these problems directly. False and short reeling were becoming increasingly difficult to prevent, at the same time as they impeded efforts to move up the quality ladder.

By the I750s, the legal position of false and short reeling had changed from that of the seventeenth century. A clear-cut body of statute law, national in scope, existed for prosecuting the offence. The Act of $\mathrm{I}_{703}$ made false and short reeling, along with embezzlement by outworkers, a specific summary offence wherever it took place, liable to a fine equivalent to double damages, or fourteen days' hard labour in the House of Correction and a whipping if unable to pay. ${ }^{64}$ Subsequently, an Act of 1749 permitted false and short reelers, like other embezzlers, to be subjected to a period of fourteen days' hard labour in a House of Correction and a whipping, without any option of a monetary payment. ${ }^{65}$ The 1749 Act was promoted by Norwich worsted manufacturers, who were still exercised about the quality of their yarn supply, but its main target was receivers of embezzled materials in Norwich itself. 


\section{Spinners and the Law}

The master woolcombers and yarnmakers of Norfolk and Suffolk undertook sporadic prosecutions for false and short reeling under this new legislation during the I750s, stimulated in part by the example of an intense campaign in Norwich itself against other aspects of embezzlement undertaken by the city's manufacturers between I75I and I754. ${ }^{66}$ By contrast, in 1764 a group of well-connected Yorkshire manufacturers and merchants, with a strategic interest in regional economic development, embarked on a much more ambitious and innovative campaign against false and short reeling. To enforce the law, they established a private association of manufacturers, funded by subscription, reminiscent of the associations for the prosecution of felons which became widespread in the second half of the eighteenth century. ${ }^{67}$ Unlike most associations for the prosecution of felons, the manufacturers' subscription paid not only the cost of prosecutions, but also the salaries of at least two inspectors whose job was to detect offenders. ${ }^{68}$ The number of prosecutions was relatively small (the York Courant reported eighteen convictions in 1764 and I765, almost certainly only a fraction of the total), but the private, salaried industrial police force was a significant innovation.

Precisely where the idea of an inspectorate came from is not clear. Before the eighteenth century, the word most widely used to describe guild officials who checked for faulty work was 'searcher'. The word 'searcher' continued to be used in this sense in eighteenth-century parliamentary legislation. The Yorkshire worsted manufacturers must have been familiar with the salaried searchers in the West Riding woollen industry, appointed under statute by the West Riding Quarter Sessions to check the dimensions of broad and narrow cloths at fulling mills. ${ }^{69}$ In 1764 , however, local industrial precedents were lacking for the use of the word 'inspector'. Yorkshire worsted manufacturers' decision to use the term suggests familiarity with the inspectors employed by the Board of Trustees of the Linen and Hempen Manufactures of Ireland after I7I9 and the Scottish Board of Trustees for Fisheries and Manufactures after I748, in each case specifically to search for badly spun and improperly reeled linen yarn offered for sale. ${ }^{70}$ The Scottish example was probably the more influential. Whereas the Irish Board of Trustees dismissed all but one of its inspectors in 1757 , the Scottish Board appointed additional yarn inspectors in I76I, just three years before the Yorkshire initiative, and launched a new and very public campaign against the sale of short and falsely reeled yarns. ${ }^{7 \mathrm{r}}$

In $\mathrm{I} 768$, only four years after inspectors were first appointed in Yorkshire, the master woolcombers and yarnmakers who employed worsted spinners in East Anglia adopted the Yorkshire model of an inspectorate funded by subscription. The result, as in Yorkshire, was a marked increase in the number and consistency of convictions for false and short reeling, with eighteen reported in the Norwich Mercury in 1769 and twenty-seven in 1770 (compared with one in 1766 and none in 1767 ). However, the vertically disintegrated structure of the Norwich-based industry persisted and with it tensions between weaving employers and spinning employers. The new East Anglian inspectorates were established by the woolcombers and yarnmakers because the Norwich weaving manufacturers who bought their yarn insisted on it. ${ }^{22}$ By the mid-eighteenth century, the capacity of the Norwich manufacturers, now organised in their unofficial committee, to impose their will on the East Anglian woolcombers and makers of yarn was probably greater than it had been in the seventeenth century. It was bolstered by their increasing use of Irish yarn, which by the I770s comprised about a sixth of the city's yarn consumption. ${ }^{73}$ 
The introduction of inspectorates in East Anglia in I768 marked the beginning of a sustained campaign in the region against false and short reeling. It was to last until the demise of hand spinning at the start of the nineteenth century. This campaign was not a response to labour shortages and associated problems of labour discipline. Essex worsteds were already in long-term decline, while the Norwich industry was no longer expanding. Nor was the campaign indicative of some wholly new concern to eliminate perquisites. It can be better explained in terms of a shift in the balance of power between the weaving sector of the industry and the spinning sector, brought about by the increased use of Irish yarn, by the adoption of the new, more systematic policing technique borrowed from Yorkshire and perhaps by an increased capacity for concerted action as the Norwich trade became increasingly dominated by a small group of large merchant-manufacturers in the second half of the eighteenth century.

So successful was the inspectorate system in East Anglia that in 1774 Norwich, Norfolk and Suffolk MPs secured the passage of an Act reducing the corporal and custodial penalties for false and short reeling to a relatively small $(5 s)$ financial forfeiture for the first offence. ${ }^{74}$ The preamble to the Act explained this reduction was necessary because the severity of the existing penalties had discouraged prosecutions and deterred honest, industrious people from spinning. The timing also suggests adaptation to a broader national trend which saw public corporal punishment completely abandoned between I750 and I800 for female criminals. ${ }^{75}$ In effect, this Act completed a process whereby severe punishments imposed in terroram were replaced by much more systematic enforcement of milder penalties by inspectors.

In Yorkshire, meanwhile, the inspectorate system began to run into difficulties in the late I760s and early I770s. The Yorkshire industry continued to grow (albeit in fits and starts) and used little Irish yarn. Pressure on local yarn supplies increased. Given this was an industry with a 'great number of ... master manufacturers and the rivalship consequential thereon', there was a considerable temptation for some manufacturers to break ranks, leave the subscription which funded the inspectors, and attract spinning labour by tolerating false and short reeling. ${ }^{76}$ By 1776 the inspection of yarn had collapsed, and it was said that manufacturers in general did not dare prosecute 'for fear of becoming unpopular among the spinners and losing their work'. ${ }^{77}$ This prompted worries that Yorkshire would become uncompetitive, because 'in most other seats of the worsted manufactory in England, the laws respecting spinners are executed', especially where the subscription inspectorate system flourished, as in East Anglia. ${ }^{7}$

It was in the face of this breaking of ranks that the original promoters of the inspectorate scheme sponsored the first of the Worsted Acts, passed in 1777 and encompassing the spinning zone of the West Riding worsted industry in Yorkshire, Lancashire and Cheshire. Essentially, it was a means of forcing solidarity on the manufacturers in the industry by law. The committee of manufacturers that supervised inspectors was now to be a body established by statute, the inspectors it appointed were to be licensed by the local Justices of the Peace and expenses were met by a levy on the industry administered through the machinery of the excise. There were some similarities here with the West Riding woollen industry, where the searchers of broad and narrow cloth who operated under statute were licensed by the Justices of the Peace in Quarter Sessions. But much more direct parallels lay in the state-funded boards of trustees for 


\section{Spinners and the Law}

manufactures established by statute in Ireland in I7II and Scotland in I727, in the Irish case funded partly out of customs revenues. ${ }^{79}$ As we have seen, the Scottish Board of Trustees for Fisheries and Manufactures had appointed salaried linen yarn inspectors in I748. It is striking that in the first published draft of the I777 Worsted Act, the body the Act was eventually to call 'the committee of the manufacturers' was initially termed 'the trustees'.80

The impact of the statutory inspectorate system was dramatic. In Cheshire, where the evidence is particularly strong, there were only eight convictions recorded for false and short reeling of worsted yarn in the five years 1770 to $\mathrm{I} 774$, but in the five years I778 to I782, when the statutory inspectorate was operating, there was an annual average of fifty-six. ${ }^{8 \mathrm{I}}$ The less complete figures for the West Riding suggest an even more spectacular increase, with, for example, well over two hundred convictions recorded in I780 alone. $^{82}$

The model provided by the 1777 Worsted Act for Yorkshire, Lancashire and Cheshire was, over the course of the subsequent fifteen years, adopted by most of the worsted spinning counties in the East Midlands and East Anglia, but for different reasons. Here, in contrast to the north, spinning was in decline. In several of these counties, existing subscription-funded committees managing inspectors appear to have functioned effectively, but increasing competition from Yorkshire and the prospect of secure funding through the excise system may have encouraged the change to a statutory system. Last to change, in I79I, were the woolcombers and makers of yarn in Norwich and Norfolk. Whether their tardiness in adopting a Worsted Act reflected continuing tensions with the Norwich worsted weavers within their still vertically disintegrated industry remains unclear.

\section{CONCLUSION}

Herbert Heaton, the historian of Yorkshire's early modern woollen and worsted industries, noted that the Worsted Acts of the later eighteenth century generated a system of industrial regulation with remarkable similarities to the guilds of the previous century. ${ }^{8} 3$ Those guilds may have ceased to function, but the demand for officially endorsed regulation evidently had not. In the putting-out worsted industries of the seventeenth and eighteenth centuries, yarn was a key intermediate good, its integrity a matter of crucial importance to the quality of worsted fabrics and their makers. But monitoring yarn standards, whether within vertically integrated firms, or in commercial transactions between yarn suppliers and yarn users, was a significant transaction cost. It was a cost which some employers in the industry were inclined to avoid. For others, the value of monitoring was called into question when tight labour markets caused the enforcement of standards to conflict with access to the spinning labour force. Legally enforced regulations offered ways of addressing these dilemmas, though they might vary according to the organisation of each regional industry. However, the institutional repertoire for creating and enforcing such regulations changed dramatically between the seventeenth and the eighteenth centuries.

Like seventeenth-century guilds, the manufacturers' committees established under the Worsted Acts were funded by local industries, enforced standards, inspected products 
and initiated prosecutions. Yet they also differed in significant respects. The eighteenthcentury committees were narrowly targeted on a single set of offences - false and short reeling - which constituted the most acute monitoring problem within the worsted industries. They lacked the kind of general powers characteristic of earlier guilds to search and enforce standards across whole industries with regard to cloth dimensions or apprenticeship. They were established by parliamentary legislation, not by the exercise of the royal prerogative or municipal ordinance. They administered the detection and prosecution of statutory offences tried by Justices of the Peace; they had no judicial functions of their own. Their funding came not from a direct levy on participants in the industry, but indirectly via the state's new and highly efficient excise bureaucracy. Their searches for defective work were conducted not by their own members or part-time officials, as had often been the case with guilds, but by well-salaried, full-time inspectors. These inspectors applied the new bureaucratic technology of surveillance developed over the previous century by the excise service, following regular circuits, keeping exhaustive paper records, and subject to systematic monitoring of their own performance. Inspection ranged far beyond guildhalls and urban marketplaces, extending from village to village across huge swathes of rural England. These differences reflected changes in the way laws could be made, in the powers and institutions legislation could provide, and in the capacity of bureaucratic systems to fulfil administrative goals set for them. ${ }^{84}$

Eighteenth-century British Parliaments maintained a monopoly on law-making and were reluctant to establish corporate economic institutions with wide-ranging regulatory authority. The result was a highly particularistic mode of legislating, which created, at the behest of powerful private interests, a huge number of local bodies to perform narrowly defined economic purposes - turnpikes, enclosures, urban improvements and the like. The four late-eighteenth century Worsted Acts, enacted at different dates for different counties, were characteristic products of this approach to law-making. ${ }^{85}$ They did not arise from any demand for general regulation of their industry, but rather from the shortcomings of pre-existing, informal arrangements. The outcome was not an absence of industrial regulation, but a particular mode of regulation - narrow and reactive, though not necessarily ineffective.

As Julian Hoppit has emphasised, such an approach was not inevitable in a parliamentary system. In the eighteenth-century Irish Parliament, general legislation applying to the country as a whole predominated, and in both Ireland and Scotland the state was more willing than in England to use public funds to encourage and regulate manufacturing. ${ }^{86}$ Indeed, Conrad Gill described Irish efforts to promote the linen industry in the eighteenth century as 'Parliamentary Colbertism' ${ }^{87}$ It would be impossible to characterise the Worsted Acts in that way. They included provisions similar to some of those implemented by the Irish and Scottish Boards of Trustees for linens, but they were a piecemeal response to a specific problem, not elements in an aggressive, comprehensive policy, designed to establish internationally competitive textile manufacturing in their respective countries. The Worsted Acts demonstrate that options for industrial regulation existed in eighteenth-century England, but also reveal its limitations. 


\section{Spinners and the Law}

\section{GLOSSARY}

Bay Usually a napped fabric with a worsted warp and a woollen weft.

Calamanco An all-worsted fabric, often striped, flowered, or glazed, much used for petticoats in the eighteenth century.

Everlasting A tightly woven all-worsted fabric, often patterned with small figures and in the eighteenth century used for the uppers of women's shoes.

Fustian For most of the seventeenth and eighteenth centuries, a fabric with a linen warp, a cotton weft and a napped surface. In the sixteenth century, however, some fustians incorporated worsted yarn, while by the end of the eighteenth century all-cotton fustians were becoming the norm.

Russel An all-worsted fabric, often patterned and glazed, used for clothes and furnishings.

Say A term used in the sixteenth and seventeenth centuries to describe a wide range of lightweight fabrics woven, at least in part, with yarns spun from scoured, long-staple wool. Introduced from Flanders in the sixteenth century, says were used both for clothing and furnishings. Some were all worsted, some had a worsted warp and a woollen weft, others incorporated silk yarns.

Serge A napped fabric with a worsted warp and a woollen weft.

Shalloon An all-worsted fabric, often fairly coarse, used for clothes.

Stuff A generic term for fabrics woven exclusively from yarn spun from long-staple wool, or combined with mohair or silk yarns. By the eighteenth century 'stuff' was being superseded as a generic term by 'worsted'.

Tammy An all-worsted fabric with a lustrous finish, used for clothes and furnishings.

Worsted Originally, in the mid-sixteenth century, yarn tightly spun from long-staple Norfolk wool in its natural oil on a drop spindle, or the fabric woven from it. In the seventeenth and eighteenth centuries, the word increasingly came to be used generically to describe any yarn spun from long-staple wool, irrespective of how it was spun, and any fabric woven with it. It is this second, generic usage that is employed in this article.

Worsted fabrics underwent a process of constant adjustment and innovation between I 550 and I 800 , so definitions are necessarily approximate. For further information, see F. Montgomery, Textiles in America, 1650-1870 (London and New York: Norton, 1984), which deals not just with America, but with textiles throughout the British Atlantic world.

\section{ACKNOWLEDGEMENTS}

The research leading to these results has received funding from the European Research Council under the European Union's Seventh Framework Programme (FP/2007-20I3) / ERC Grant Agreement no. 2495I2. The author is grateful for comments and suggestions to Donna Andrew, David Celetti, Alice Dolan, Joanna Innes, Norma Landau, Amanda Vickery and audiences at conferences at the Universities of Birmingham and Reading, as well as the Maison des Sciences de l'Homme in Paris, where versions of this article were presented.

\section{REFERENCES}

${ }^{\mathrm{I}}$ E. Lipson, The History of the Woollen and Worsted Industries (London: A. and C. Black, I92I), p. 69.

${ }^{2}$ S. A. Margolin, 'What do bosses do? The origins and functions of hierarchy in capitalist production', The Review of Radical Political Economics, vi (1974), pp. 46-55.

${ }^{3}$ For an assessment of previous interpretations, see J. Styles, 'Embezzlement, industry and the law in England, I500-1800', in M. Berg, P. Hudson and M. Sonenscher eds, Manufacture in Town and Country before the Factory (Cambridge: Cambridge University Press, 1983), pp. I88-205. For more 
recent works, see C. Becker, 'Property in the workplace: labor, capital, and crime in the eighteenthcentury British woollen and worsted industry', Virginia Law Review, LXIX (I983), pp. I487-I5I5; A. J. Randall, 'Peculiar perquisites and pernicious practices: embezzlement in the West of England woollen industry, c. I750-1840', International Review of Social History, XXXV (1990), pp. I93-219; P. Linebaugh, The London Hanged: Crime and Civil Society in the Eighteenth Century (London: Allen Lane, I99I), esp. ch. 7; L. Hilaire-Perez, 'Le vol des déchets dans l'industrie en France et en Angleterre au XviII siècle. Jalons pour une histoire comparée de l'embezzlement', in B. Garnot ed., La Petite Délinquance du Moyen Âge à l'Époque Contemporaine (Dijon: EUD, I998), pp. 28I-308; D. W. Allen, The Institutional Revolution: Measurement and the Economic Emergence of the Modern World (Chicago: University of Chicago Press, 20I2), ch. 8; B. Godfrey and D. J. Cox, Policing the Factory: Theft, Private Policing and the Law in Modern England (London: Bloomsbury Academic, 2013), esp. chs I and 2.

${ }^{4}$ B. Godfrey, 'The impact of the factory on workplace appropriation in mid to late nineteenthcentury Yorkshire', British Journal of Criminology, XxxIx (1999), pp. 56-7I; Styles, 'Embezzlement, industry and the law'.

5Styles, 'Embezzlement, industry and the law', pp. 200-05.

${ }^{6}$ R. Soderlund, 'Resistance from the margins: the Yorkshire worsted spinners, policing, and the transformation of the early Industrial Revolution', International Review of Social History, LI (2006), pp. $235-36$.

${ }^{7}$ I7 Geo. III, c. II (I777) for Yorkshire, Lancashire and Cheshire; 24 Geo. III, St. 2, c. 3 (I784) for Suffolk; 25 Geo. III, c. 40 (I785) for Bedfordshire, Huntingdonshire, Northamptonshire, Leicestershire, Rutland, Lincolnshire and the Isle of Ely; 3I Geo. III, c. 56 (I79I) for Norfolk and Norwich.

${ }^{8}$ For an early use of the phrase 'Worsted Acts', see J. James, The History of the Worsted Manufacture in England (London: Longman, I857), p. 294. James used the phrase to refer both to the Yorkshire, Lancashire and Cheshire inspectorate Act of I777 (I7 Geo. III, c. II) and to the general industrial embezzlement Act of the same year ( $\mathrm{I} 7$ Geo. III, c. 56 [misprinted in James as c. I6]), which was initiated by the Members of Parliament for Norwich and Norfolk. However, in its early years, the Yorkshire, Lancashire and Cheshire committee referred to its own statute as 'the Worsted Act', but termed the general industrial embezzlement acts 'the Norwich Acts'. See Leeds Intelligencer, 2 November I779, and Worsted Committee Minute Book, I777-I786, 2I June I779, Wc/I/I, West Yorkshire Archives Service, Bradford. The term 'Worsted Act' is used in this article to refer only to the four acts that established inspectorates.

9 James, The History of the Worsted Manufacture, pp. 292-98; H. Heaton, The Yorkshire Woollen and Worsted Industries: From the Earliest Times up to the Industrial Revolution (Oxford: Oxford University Press, I965), pp. 4I8-35; R. Soderlund, "Intended as a terror to the idle and profligate": embezzlement and the origins of policing in the Yorkshire worsted industry, c. 1750-1777', Journal of Social History, Xxxi (I998), pp. 647-69; Soderlund, 'Resistance from the margins', pp. 2I7-42.

${ }^{\text {ro }}$ For recent work on guilds, see S. R. Epstein and M. Prak eds, Guilds, Innovation and the European Economy, I400-I800 (Cambridge: Cambridge University Press, 2008). For state regulation in France, see P. Minard, 'Colbertism continued? The inspectorate of manufactures and strategies of exchange in eighteenth-century France', French Historical Studies, XXIII (2000), pp. 477-96 and in Britain, P. Gauci ed., Regulating the British Economy, I660-I850 (Farnham: Ashgate, 20II).

${ }^{\text {II }}$ For the use of the transaction cost approach to re-evaluate the role of guilds, see Epstein and Prak eds, Guilds, Innovation and the European Economy, especially S. R. Epstein and M. Prak, 'Introduction: guilds, innovation, and the European economy, I400-I800', pp. I-24 and U. Pfister, 'Craft guilds, the theory of the firm, and early modern proto-industry', pp. 25-5I. For a critique, see S. Ogilvie, 'Guilds, efficiency and social capital: evidence from German proto-industry', Economic History Review, LVII (2004), pp. 286-333.

${ }^{12}$ Natural variance of materials is discussed in Allen, The Institutional Revolution, esp. ch. 2, although his insistence that significant standardisation came only with the Industrial Revolution is mistaken. 


\section{Spinners and the Law}

${ }^{13}$ For 'quality covenants', see P. Minard, 'Facing uncertainty: markets, norms and conventions in the eighteenth century', in Gauci ed., Regulating the British Economy, p. I86.

${ }^{14}$ For the economics of conventions, see R. Salais and M. Storper, Worlds of Production: The Action Frameworks of the Economy (Cambridge, Mass.: Harvard University Press, 1997). For its application to early modern Europe, see Minard, 'Facing uncertainty', pp. I77-94 and C. Jeggle, 'Economics of quality as a concept of research on luxury', in R. Rittersma ed., Luxury in the Low Countries: Miscellaneous Reflections on Netherlandish Material Culture, I 500 to the Present (Brussels: VUB University Press, 20I0), pp. 25-40.

is West Riding of Yorkshire Quarter Sessions, Memoranda of Summary Convictions, I778-I800, QEI5/I-42, West Yorkshire Archives Service, Wakefield.

${ }^{16}$ James, The History of the Worsted Manufacture, p. 28I. Earlier estimates suggested even higher proportions of spinners to woolcombers and weavers. See James, The History of the Worsted Manufacture, pp. 2II, 2I8. Also see C. Muldrew, “"Th'ancient distaff” and "whirling spindle”: measuring the contribution of spinning to household earnings and the national economy in England, I550-I770', Economic History Review, LXV (20I2), pp. 498-526.

${ }^{17}$ S. Finney, 'Survey of the parish of Wilmslow', in T. Worthington Barlow ed., The Cheshire and Lancashire Historical Collector, II (I853), pp. 6-7; J. Tuke, A General View of the Agriculture of the North Riding of Yorkshire (London: I800), p. 3I2; T. W. Hanson, 'Jonathan Ackroyd's account books', Transactions of the Halifax Antiquarian Society (1939), p. I40; Journals of the House of Commons, XI (I693-I697), p. 22.

${ }^{18}$ Piece rates for spinners employed by bay and say makers in Essex in 1575 were calculated according to length, measured on a yard reel; J. E. Pilgrim, 'The Cloth Industry in Essex and Suffolk, I558-I640' (Unpublished MA thesis, University of London, I938), p. I 57.

${ }^{19}$ For the use of the term 'reel staff' in 1636, see R. Sanderson, Foedera, xx (London: 1735), p. 4I.

${ }^{20}$ See the later medieval images of hand reels illustrated in K. Larsdatter, 'Tools for Winding Thread or Yarn', Medieval and Renaissance Material Culture (Online). Available from: www. larsdatter.com/winding.htm [Accessed: 3 April 20I3].

${ }^{21}$ Letter to the Mayor of Norwich, 23 October I6I6, Privy Council Registers, I6I5-I6I7, PC 2/28, f. 435, The National Archives (TNA), London.

${ }^{22}$ D. J. Jeremy, 'British and American yarn count systems: an historical analysis', Business History Review, XLV (I97I), pp. 336-68; N. Biggs, 'A tale untangled: measuring the fineness of yarn', Textile History, xxxv, no. I (2004), pp. I20-29. The existence of different regional systems for reeling does not appear to have seriously inhibited inter-regional trade in yarn. Diversity was rarely identified as a problem by those involved in the industry. Manufacturers were more concerned with ensuring adherence to the various local standards than with securing a uniform, national measure. A brief attempt in I636 to impose by royal proclamation a limited number of standard or 'constant' reels for all yarns made from wool or flax came to nothing; see Sanderson, Foedera, xx, pp. 4I-46.

${ }^{23}$ James, The History of the Worsted Manufacture, p. 28I.

${ }^{24}$ Worsted Committee Minute Book, I777-I786, I9 June I780, WC/I/I, West Yorkshire Archives Service, Bradford. The same distinction was made in the Scottish linen manufactory, using a slightly different vocabulary: 'bad Tell [tale] or short Reels'. See D. Ramsay, The Weaver and Housewife's Pocket Book Containing Rules for the Right Making of Linen Cloth (Edinburgh: 1750), p. 8.

${ }^{25}$ Lancashire Quarter Sessions, Recognizance Rolls, convictions of Betty Dagnell and Ellen Atherton, 6 June I785, QSB/I/July I785, Lancashire Archives, Preston.

${ }^{26}$ See Styles, 'Embezzlement, industry and the law', pp. I88-99. These statutes combined elements of restitution and punishment in a muddled mixture of civil and criminal modes identified by Peter King as characteristic of summary court practice in general. See P. King, Crime and Law in England, I750-I840: Remaking Justice from the Margins (Cambridge: Cambridge University Press, 2006), p. 23. 
${ }^{27}$ For regulations prohibiting the sale of falsely reeled linen yarn by spinners in local markets, see North Riding of Yorkshire Quarter Sessions Bundles, I726, QSB/I726, North Yorkshire County Record Office, Northallerton. For falsely reeled yarn in the international bulk linen yarn trade involving large merchants and manufacturers, see John and Nathaniel Philips to Van Wylick, 7 May I766, Faulkner Philips diaries and papers, Correspondence and orders, I753-1769, M97/3, Manchester Archives and Local Studies, Manchester: 'we must beg leave to observe to you that there are a parcel of I50 bundles of it bad uneven spinning and dishonest count'.

${ }^{28}$ A. P. Wadsworth and J. de L. Mann, The Cotton Trade and Industrial Lancashire, $1600-I 780$ (Manchester: Manchester University Press, 1965), p. 397.

${ }^{29}$ For example, Coventry in I5I8: M. Dormer Harris, The Coventry Leet Book, II (London: Published for the Early English Text Society by Kegan Paul, Trench, Trübner \& Co., I909), pp. 656-57; Bury St Edmunds in I609: Copy of regulations for the corporation of clothiers, etc., Bury Collection, D 9/r/b, Suffolk Record Office, Bury St Edmunds; the west of England in I774: Journals of the House of Commons, XXXIV (I772-I774), pp. 45 I-52.

${ }^{30}$ For eighteenth-century evidence of payment by weight for spinning short-staple wools, see Anon., The Interest of England in Relation to the Woollen Manufacture (London: printed for John Nut, I70I), p. I7, and the national survey of spinning wages undertaken by Arthur Young in the I780s: A. Young, 'On the prices of wool, and state of spinning at present in England', Annals of Agriculture, IX (I788), pp. 266-376. However, the situation was not static. In I788 at Pucklechurch in Gloucestershire the spinners of short-staple, carded wool had previously been paid by weight, but recently there had been a shift to payment by quality. Young, 'On the prices of wool', p. 297.

${ }^{3}$ Worsteds had, of course, been produced in Norfolk during the later Middle Ages. There were important continuities between these earlier worsteds and the newer Norwich stuffs which, with the stimulus of skilled immigrants from the Low Countries, became so successful from the later sixteenth century. But there were also significant differences. The old worsteds had declined, or at best stagnated, in the mid-sixteenth century, while the new stuffs were characterised by an ever-expanding range of products employing a wider range of yarn types. These yarns came to be produced on a putting-out basis by large-scale woolcombers and yarn makers, whereas spinners of the old worsted yarn had bought small quantities of wool from broggers and combed it themselves. See J. Oldland, "“Fyne worsted whech is almost like silke": Norwich's double worsted', Textile History, xuII, no. 2 (20II), pp. I8I-99; K. J. Allison, 'The Norfolk worsted industry in the sixteenth and seventeenth centuries, I: the traditional industry', Yorkshire Bulletin of Economic and Social Research, XII (I960), pp. 73-83, especially p. 76; K. J. Allison, 'The Norfolk worsted industry in the sixteenth and seventeenth centuries, 2: the new draperies', Yorkshire Bulletin of Economic and Social Research, XIII (I96I), pp. 69-70. For the take-up of power-spun yarn, see James, The History of the Worsted Manufacture, pp. $355-56$.

${ }^{32}$ Muldrew, “Th'ancient distaff” and "whirling spindle", p. 5 I7.

${ }^{33}$ London should probably be added to this list, but evidence about the size and character of the London industry is extremely sparse. For all the regional worsted industries, see James, The History of the Worsted Manufacture.

${ }^{34}$ Allison, 'The Norfolk worsted industry in the sixteenth and seventeenth centuries, 2: the new draperies', pp. 6I-77; L. N. D. Martin, 'Textile Manufactures in Norwich and Norfolk, I550-I622' (Unpublished $\mathrm{PhD}$ thesis, University of Cambridge, I99I); P. J. Corfield, 'The Social and Economic History of Norwich, I650-I850' (Unpublished PhD thesis, University of London, I976); J. K. Edwards, 'The Economic Development of Norwich, I750-I850, with Special Reference to the Worsted Industry' (Unpublished PhD thesis, University of Leeds, I963).

${ }_{35}$ Pilgrim, 'The Cloth Industry in Essex and Suffolk'; K. H. Burley, 'The Economic Development of Essex in the Later Seventeenth and Early Eighteenth Centuries' (Unpublished PhD thesis, University of London, 1957), ch. 4 . 


\section{Spinners and the Law}

${ }^{36}$ W. G. Hoskins, Industry, Trade and People in Exeter, I688-1800 (Exeter: University of Exeter Press, I968).

${ }^{37}$ Heaton, The Yorkshire Woollen and Worsted Industries; M. Dickenson, 'The West Riding Woollen and Worsted Industries, I689-I770: An Analysis of Probate Inventories and Insurance Policies' (Unpublished $\mathrm{PhD}$ thesis, University of Nottingham, 1974).

${ }^{38}$ I Anne, Stat. 2, c. I8 (I703).

39 Allison, 'The Norfolk worsted industry in the sixteenth and seventeenth centuries, 2: the new draperies', pp. 74-76; Corfield, 'The Social and Economic History of Norwich', pp. 8I-84; 'The Norwich and Norfolk Weavers Answer to the Petition and Case of the Wool-Combers', not dated (c. I693-I694), State Papers Domestic, Charles II, SP 29/75, f. 275, TNA; 'The Case of the WoollCombers and Traders', I693, State Papers Domestic, William and Mary, SP 32/13, f. I76, TNA; 'A Brief Reply to the Weavers Answer to the Wool-Combers Petition and Case', not dated (c. I693-I694), British Library, London.

${ }^{40}$ Irish Statute 7 Geo. II, c. 9 (I733).

${ }^{41}$ Corfield, 'The Social and Economic History of Norwich', pp. 72, 74.

${ }^{42}$ Quoted in U. Priestley, 'Norwich stuffs, I600-I700', in N. Harte ed., The New Draperies in the Low Countries and England, I300-I800 (Oxford: Oxford University Press, I997), p. 278.

${ }^{43}$ For a I608 example of a yarnmaster holding large stocks of yarn, see Martin, 'Textile Manufactures', p. II4.

${ }^{44}$ Burley, 'The Economic Development of Essex', pp. I25-26.

${ }^{45}$ See the examples of corporal punishment of embezzlement offenders in the Wiltshire woollen industry in the mid-sixteenth century, quoted in B. H. Cunnington, Some Annals of the Borough of Devises: Being a Series of Extracts from the Corporation Records, I555 to I79I (London: George Simpson, I925), I, pp. I5, 36, and II, p. 3. At this date, there was no Act of Parliament dealing explicitly with industrial embezzlement that authorised such punishments. Two centuries later, the statutory foundations for many of the decisions made by magistrates acting summarily remained weak; see King, Crime and Law in England, pp. 30-3I.

${ }^{46} 7$ Jac. I, c. 7 (I609).

${ }^{47}$ Ibid. I have been unable to discover evidence as to whether or how this legislation was used against false and short reelers, although the lack of evidence is a result of the failure of appropriate sources to survive and should not be taken to mean that the Act was never used.

${ }^{48}$ I2 Car. II, C. 22 (I660). The terms company and guild are used interchangeably in this article. In all cases, they refer to collective organisations of master manufacturers, in other words the employers in their respective trades.

${ }^{49}$ Pilgrim, 'The Cloth Industry in Essex and Suffolk', pp. 75-83, II 5-I9; Burley, 'The Economic Development of Essex', p. I28.

${ }^{50}$ Martin, 'Textile Manufactures', pp. 38-39, II2-I3, 258-95; C. H. Firth and R. S. Rait eds, Acts and Ordinances of the Interregnum, II (London: HMSO, I9II), p. 490; I3 \& I4 Car. II, c. 5 (I662).

${ }^{51}$ The legal challenge to the capacity of acts of the royal prerogative, such as guild charters, to grant powers of search, fine and forfeiture came after I700; see I. Anders Gadd and P. Wallis, 'London guilds and national regulation, I500-I700', in Epstein and Prak eds, Guilds, Innovation and the European Economy, pp. 300, 3 I3 3 .

${ }_{52}$ Letter to the Mayor of Norwich, 26 May I6I7, Privy Council Registers, I6I7-I6I8, PC 2/29, f. 4 I, TNA.

${ }_{53}$ Reports of meetings at Bury St Edmunds between the weavers and the yarnmakers, 28 July I629; 4 December I629; I4 December I629, State Papers Domestic, Charles I, SP I6/I47, f. 75; SP I6/I53, ff. I8, 96, TNA. For the woolcombers' and yarnmakers' petition to Parliament for incorporation, see Journals of the House of Commons, XI (I693-I697), p. 22 and for context, Corfield, 'The Social and Economic History of Norwich', pp. 8I-84.

${ }^{54}$ Styles, 'Embezzlement, industry and the law', pp. I8I-88. 
${ }^{55}$ D. Defoe, A Tour thro' the Whole Island of Great Britain, II (London: I724), p. 9I. For competition for spinners early in the seventeenth century, see Martin, 'Textile Manufactures', p. 232.

${ }^{56}$ Petition and certificate of the makers and weavers of worsted, bays, says, stuffs, and fustians in Norfolk, Suffolk and Essex, not dated (March I623), State Papers Domestic, James I, SP I4/I40, f. I33, TNA.

${ }_{57}$ T. Kiern, 'Parliament, legislation and the regulation of English textile industries, I689-I7I4', in L. Davison, T. Hitchcock, T. Kiern and R. Shoemaker eds, Stilling the Grumbling Hive: The Response to Social and Economic Problems in England, I689-I750 (Stroud: Alan Sutton, I992), pp. I-24; J. Hoppit, J. Innes and J. Styles, 'Project report: towards a history of parliamentary legislation, I660I800', Parliamentary History, XIII (I994), pp. 3I2-2I; J. Hoppit, 'Patterns of parliamentary legislation, I660-I800', Historical Journal, Xxxix (I996), pp. I09-3I. For a provocative reinterpretation of these developments, see S. Pincus and J. A. Robinson, 'What really happened during the Glorious Revolution?', National Bureau of Economic Research, Working Paper No. I7206 (Cambridge, Mass.: 20II).

${ }^{58} \mathrm{~J}$. P. Cooper, 'Economic regulation and the cloth industry in seventeenth-century England', Transactions of the Royal Historical Society, 5 th series, Xx (1970), pp. 73-99.

${ }^{59}$ M. Walker, 'The Extent of the Guild Control of Trades in England, c. I660-I820' (Unpublished $\mathrm{PhD}$ thesis, University of Cambridge, I985).

${ }^{60}$ Burley, 'The Economic Development of Essex', pp. 153-54.

${ }^{6 \mathrm{I}}$ Corfield, 'The Social and Economic History of Norwich', p. 77.

${ }^{62}$ Leeds Intelligencer, 5 June 1764.

${ }^{63}$ James, The History of the Worsted Manufacture, pp. 263-92. For the slightly later shift to higher quality fabrics by one manufacturer near Howarth, see E. M. Sigsworth, 'William Greenwood and Robert Heaton. Two eighteenth-century worsted manufacturers', Journal of the Bradford Textile Society (195I-I952), pp. 67-68.

${ }^{64}$ I Anne, stat. 2, c. I8 (1703).

${ }_{65} 22$ Geo. II, c. 27 (I749). It is doubtful whether this Act made much practical difference to the treatment actually accorded false and short reeling offenders on conviction. See Styles, 'Embezzlement, industry and the law', pp. 190-92.

${ }^{66}$ Norwich Mercury, I8 April I752; II May I754; 22 October 1757.

${ }^{67}$ D. Philips, 'Good men to associate and bad men to conspire: associations for the prosecution of felons in England, I760-I860', in D. Hay and F. Snyder eds, Policing and Prosecution in Britain, I750-I850 (Oxford: Oxford University Press, I989), pp. II3-70.

${ }^{68}$ The association was first announced in an advertisement in the Leeds Intelligencer, 5 June 1764 , which already used the word 'inspector' to describe these agents. For a brief account of its history up to 1776 , see Leeds Intelligencer, 26 November 1776.

${ }^{69}$ The Acts of Parliament for the West Riding woollen industry that used the word 'searcher' were 7 Anne, c. I3 (I708); II Geo. I, c. 24 (I724); 7 Geo. II, c. 25 (I734); II Geo. II, c. 28 (I738) and I4 Geo. II, c. 35 (I738). The first use of the word 'inspector' in legislation regulating the West Riding woollen industry came after I764, in 5 Geo. III, c. 5I (I765). 'Inspector' had been used earlier in I3 Geo. I, c. 23 (I726), which regulated the woollen industry in Gloucestershire, Wiltshire and Somerset.

${ }^{70}$ C. Gill, The Rise of the Irish Linen Industry (Oxford: Oxford University Press, 1925), pp. 68, 78, 97; A. J. Durie, The Scottish Linen Industry in the Eighteenth Century (Edinburgh: John Donald, I979), p. 74 .

${ }^{71}$ Caledonian Mercury, 25 May I76r. The context of this Scottish campaign was a marked increase in linen yarn prices and associated anxieties about yarn quality. See T. Griffiths, P. Hunt and P. O'Brien, 'Scottish, Irish, and imperial connections: Parliament, the three kingdoms, and the mechanization of cotton spinning in eighteenth-century Britain', Economic History Review, LXI, issue 3 (2008), pp. 640-4I.

${ }_{72}$ Norwich Mercury, 23 July I768; 20 August 1768.

${ }^{73}$ Corfield, 'The Social and Economic History of Norwich', p. 322. 


\section{Spinners and the Law}

${ }^{74}$ I 4 Geo. III, c. 44 (I774).

${ }^{75}$ King, Crime and the Law in England, p. 6.

${ }^{76}$ Leeds Intelligencer, 24 September 1776.

77 Ibid., 26 November 1776.

${ }^{78}$ Ibid., I2 March 1776.

${ }^{79}$ Durie, The Scottish Linen Industry, pp. I4-20; Gill, The Rise, pp. 66-68.

${ }^{80}$ Leeds Intelligencer, 24 September 1776.

${ }^{81}$ House of Correction Calendars and conviction certificates, Cheshire Quarter Sessions, Sessions Files, I770-83, QJF 198-2II, Cheshire Record Office, Chester; 'An Account of frauds and offences committed by the spinners and others employed in the Worsted Manufactory, I778-83', MS f 338.4 WI, Greater Manchester Archives and Local Studies, Manchester.

${ }^{82}$ West Riding of Yorkshire Quarter Sessions, Memoranda of Summary Convictions, I780, QEI 5/7Io, West Yorkshire Archives Service, Wakefield.

${ }^{83}$ Heaton, The Yorkshire Woollen and Worsted Industries, p. 434.

${ }^{84}$ For the excise as a model for eighteenth-century bureaucracy, see J. Torrance, 'Social class and bureaucratic innovation: the Commissioners for Examining the Public Accounts, $1780-1787$ ', Past and Present, LXXviI, no. I (1978), pp. 56-8I; J. Brewer, The Sinews of Power: War, Money and the English State, I688-I783 (London: Unwin Hyman, I989), pp. I04-I3.

${ }^{85}$ There are parallels here with the legislation on standards for the West Riding woollen industry, discussed most recently in Minard, 'Facing uncertainty', pp. 27I-90.

${ }^{86} \mathrm{~J}$. Hoppit, 'The nation, the state, and the first Industrial Revolution', Journal of British Studies, L (20II), pp. 307-3I.

${ }^{87}$ Gill, The Rise, p. 197.

John Styles is Research Professor in History at the University of Hertfordshire. He is the author of The Dress of the People: Everyday Fashion in Eighteenth-Century England (London: Yale University Press, 2007). He curated the exhibition Threads of Feeling at the Foundling Museum, London in 20IO-20II. He currently holds a European Research Council Advanced Grant to research spinning in England in the era of the spinning wheel, I400 to I800. 